\title{
Crisis Transmission: Global Financial Crisis
}

\author{
Abdullah Alam \\ Department of Management Sciences, \\ International Islamic University Islamabad, Pakistan \\ Email: abdullah_alam@yahoo.com.Tel: +923215092022 \\ Received 19 April 2012; accepted 29 September 2012
}

\begin{abstract}
The aim of this paper is to explore, empirically, the channels of crisis transmission with regard to the Global financial crisis. EMP-based crisis proxy is used for eight countries, which include Argentina, Brazil, Canada, Indonesia, Japan, Korea, Mexico and Russia. The period considered for estimation was Q1 2001 - Q2 2010. Based on the Vector AutoRegression (VAR) and Ordinary Least Squares (OLS) specification, it is concluded that the competitive devaluation effect did not play significant role in the transmission of the crisis. Wake-up call and Cashin effects were the major contributing transmission channels for Global financial crisis. Indonesia, Japan and Russia showed signs of wake-up call effect, whereas Brazil and Japan recorded cash-in effect.
\end{abstract}

Keywords: Crisis Transmission, Global Financial Crisis, Competitive Devaluation Effect, Wake-up Call Effect, Cash-in Effect, Market Integration.

\section{Introduction}

Over the past few decades, numerous crises episodes have taken place. These crises have had huge impacts on the global financial markets and numerous economies derailed due to the impacts of these crises. Global financial crisis is considered to be one of the worst episodes of crises.

Global financial crisis originated from United States and worsened during September and October of 2008. Due to globalization and interconnectedness of financial markets, the crisis spread across the globe to other countries (Naveh, Torosyan and Jalaee, 2012). ${ }^{1}$ The same way, the Global financial crisis was transmitted to other industrialized, emerging and developing economies.

Credit and asset booms are considered to be two of the significant factors of emergence of the Global financial crisis. Regulatory and supervision lack also contributed to the worsening of the crisis. A lot of countries escaped the initial impact wave of the crisis. But by the September of 2008, situation in US and across Europe tightened with the bankruptcy of major banking and financial systems. As a result, impacts of the crisis were transmitted to numerous countries, which otherwise had not imported crisis effects.

This paper aims at identifying the channels through which Global financial crisis was transmitted across different countries. The channels used in this study are the competitive devaluation effect, wake-up call effect and the cash-in effect. I have used the period Q1 2001 Q2 2010 in this study in order to get an insight into the trade, exchange rate and market relationships (of the eight countries considered for this research) before and during the crisis. This paper focuses on eight G-20 member economies, which include Argentina, Brazil, Canada, Indonesia, Japan, Korea, Mexico and Russia.

The structure of this paper is as follow. Section 2 describes literature on the transmission of crisis. In section 3, research methodology is discussed. Section 4 presents the estimation results. Section 5 concludes the paper.

\section{Literature Review}

A lot of work has been done on reasons and policy resolutions of crises. The transmission of crises among connected countries and the channels through which these crises are transmitted is an area less researched. 
Gong, Lee \& Chen (2004) ${ }^{2}$ studied Asian financial crisis and divided the literature on crisis into four categories. These included explanation of causes and effects of the crisis, prevention of future episodes, policy resolutions and crisis transmission. They also mentioned that less work has been done on the transmission of crisis.

Frankel and Rose (1996) $)^{3}$ mention that an episode of financial crisis takes place when the exchange rate of a country depreciates by $25 \%$ or more.

According to Fratzscher $(2002)^{4}$, an open market cannot keep itself isolated from the events taking place in the rest of world and will react to them. US financial crisis also transmitted through similar means to the rest of the open markets. Bremnes, Gjerde \& Soettem $(2001)^{5}$ state that integration among financial markets has increased in the past few decades due to friendly regulations, open trade and advancements in technology. United States has major role to play in global context. European and other connected countries have to look into US economic policy in order to make their own policies.

Pukeliene \& Deksnyte $(2010)^{6}$ describe three types of models on causes of currency crisis. The first type views economic fundamentals as the reason of crises attacks. The second type describes self-fulfilling speculation as the reason, whereas international illiquidity is the condition considered by the third category of models.

White $(1998)^{7}$ has mentioned three channels of crisis transmission during Asian financial crisis. These channels include competitive depreciation, lenders' effect and capital outflows by foreign investors.

Goldstein $(1998)^{8}$ and Gong, Lee \& Chen $(2004)^{2}$ have described the competitive devaluation effect and the wake-up call effect as the major channels for transmission of Asian Financial Crisis. Abdullah, Asghar \& Abbas (2011) $)^{9}$ used the above mentioned two channels of crisis transmission for eight Asian countries to study the Asian financial crisis. They found that there existed some other channel(s) apart from these two mentioned channels. According to them, the other channel could be the Cash-in effect.

\section{Research Methodology}

\subsection{Financial crisis}

Different approaches are used to measure Exchange Market Pressure (EMP). The EMP measure used by Kaminsky, Lizondo and Reinhart $(1998)^{10}$, Komulainen and Lukkarila (2003) ${ }^{11}$, Abdullah, Asghar and Abbas $(2011)^{9}$ has been used in this study where changes in exchange rate and reserves have been used to calculate foreign exchange market pressure (EMP). The measure is given as:

$$
\mathrm{EMP}=\Delta \mathrm{ER}-\frac{\text { Std. Dev. of } \Delta \mathrm{ER}}{\text { Std. Dev. of } \Delta \mathrm{Res}} \times \Delta \mathrm{Res}
$$

Where, $\Delta \mathrm{ER}$ stands for change in exchange rate and $\Delta$ Res refers to change in reserves.

\subsection{Estimation model and techniques}

\subsubsection{Estimation model}

Quarterly data from 2001 to 2010 (second quarter) was used in this study. Data for the eight countries was put in equation (1) above. VAR estimation was carried out in E-Views using the equation below:

$$
E M P_{t}=A_{0}+A_{1}(L) E M P_{t-1}+\alpha_{t}
$$

where, $E M P_{t}(8 \times 1)$ is the foreign exchange market pressure index vector for the eight countries. $A_{0}(8 \times 1)$ is the vector of constants for the eight countries and $A_{1}$ $(8 \times 8)$ is the matrix of interactive EMP coefficients. $\alpha_{t}$ $(8 \times 8)$ represents random shock.

Akaike Information Criteria (AIC) or Schwartz Bayesian Criterion (SBC) was used in this study to account for the number of lags to be used.

\subsubsection{Estimation model of Crisis Transmission}

The period under consideration 2001-2010 has been divided into two sub-periods: pre-crisis period (Q1 2001 - Q4 2006) and crisis period (Q1 2007 - Q2 2010).

Following equation has been used to study the three crisis transmission channels among the eight countries.

$$
\begin{aligned}
& E M P_{x, t}=\left(A_{01}+A_{02} D\right)+\left(A_{11}+A_{12} D\right) E X P_{t x, t-n}+ \\
& \sum\left(A_{21, y}+A_{22, y} D\right) E M P_{y, t}+\left(A_{31}+A_{32} D\right) \beta_{i w, t}+\mu_{t}
\end{aligned}
$$


where, $E M P_{x, t}$ and $E M P_{y, t}$ are the EMPs of $x$ th and $y$ th countries at time $t . E X P_{x, t-n}$ is the lagged export growth of the $x$ th country at time $t-n$. Pth : is the beta of the $i$ th country's returns of the stock market relative to the world stock market returns. $D=0$ when time period is from Q1 2001 to Q4 2006 and $D=1$ when time period is from Q1 2007 to Q2 2010.

Equation (3) uses the three transmission channels for crisis, the competitive devaluation effect, wake-up call effect and the cash-in effect. Competitive devaluation effect relates to a country's currency devaluation, supplemented by currency devaluation by other competitive countries to prevent their exports from falling. Wake-up call effect includes crisis impact transmitted from other countries. For wake-up call effect, the sum of EMPs of two highest-impacting countries has been used. Cash-in effect relates to the outflow of foreign capital from a country during crisis.

\subsubsection{Data Sources}

For EMP estimation, the data for reserves, exchange rate and exports for all the eight countries was obtained from the International Monetary Fund's (IMF) International Financial Statistics (IFS) database. Quarterly data was used in this study. For beta estimation, daily data for the eight countries' stock market indices and world market stock index was obtained from Yahoo Finance and individual stock markets of the countries.

\section{Estimation Results}

Estimation results have been divided into three subsections: EMP Estimation Results, VAR Estimation Results and Transmission Channels Analysis.

\subsection{Foreign EMP estimation results}

EMP estimation has been used for describing a crisis episode. Table 1 contains the estimated EMPs of the eight countries over the period of 2006:01 to 2010:02 (quarterly data), in order to study the EMP variation of the countries before and during the Global Financial Crisis 2007. For Table 1, if an EMP index higher than 0.1 is considered to be a crisis state and between 0.05 and 0.1 to be a signal of a potential crisis episode arising; the EMPs table can give an insight into the Global Financial Crisis and its impact on the countries under consideration.

Before the Global Financial broke out, Korea and Russia did not show any signs of a crisis episode arising. Russia and Korea were hit by crisis in the third quarter of 2008. Korea started showing signs of a crisis episode from the last quarter of 2007. Argentina showed signs of a potential crisis throughout this period under consideration and was hit severely by crisis in the first

Table 1. Estimated significant EMPs (Q1 2006 - Q2 2010)

\begin{tabular}{|c|c|c|c|c|c|c|c|c|}
\hline & Argentina & Brazil & Canada & Indonesia & Japan & Korea & Mexico & Russia \\
\hline Q1 2006 & 0.02 & 0.05 & 0.12 & & & & 0.02 & \\
\hline Q2 2006 & & 0.02 & & 0.03 & & & 0.05 & \\
\hline Q3 2006 & 0.01 & & & 0.01 & 0.03 & & & \\
\hline Q4 2006 & & & & & 0.01 & & & \\
\hline Q1 2007 & 0.01 & & & 0.04 & & 0.01 & 0.01 & \\
\hline Q2 2007 & & & & & 0.05 & & & \\
\hline Q3 2007 & 0.02 & & & 0.01 & & & & \\
\hline Q4 2007 & & & 0.01 & 0.03 & & 0.02 & & \\
\hline Q1 2008 & 0.01 & & 0.04 & & & 0.07 & & \\
\hline Q2 2008 & & & 0.02 & & 0.06 & 0.05 & & \\
\hline Q3 2008 & 0.04 & 0.23 & 0.04 & 0.02 & & 0.15 & 0.05 & 0.09 \\
\hline Q4 2008 & 0.09 & 0.44 & 0.16 & 0.09 & & 0.04 & 0.26 & 0.36 \\
\hline Q1 2009 & 0.08 & 0.03 & 0.04 & 0.06 & 0.09 & 0.10 & 0.07 & 0.17 \\
\hline Q2 2009 & 0.02 & 0.32 & & & & & & \\
\hline Q3 2009 & 0.01 & & & & & & & \\
\hline Q4 2009 & & & & & 0.03 & & & 0.06 \\
\hline Q1 2010 & 2.00 & 0.05 & & & 0.02 & & & \\
\hline Q2 2010 & 0.02 & & 0.05 & & & 0.07 & 0.02 & 0.05 \\
\hline
\end{tabular}


quarter of 2010. Brazil was impacted by crisis in the third quarter of 2008 which continued for almost a year. Canada was hit by crisis in the fourth quarter of 2008 .

Indonesia showed signs of potential crisis outbreak till the first quarter of 2009 but a crisis episode was not recorded for Indonesia. Japan also did not hugely respond to the Global Financial Crisis. Mexico was hit by crisis in the last quarter of 2008. The trends of EMPs for all the countries over the period of 2006 Q1 - 2010 Q2 are shown in the figure 1.

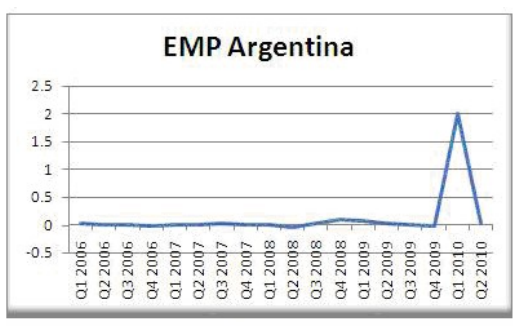

Graph 1

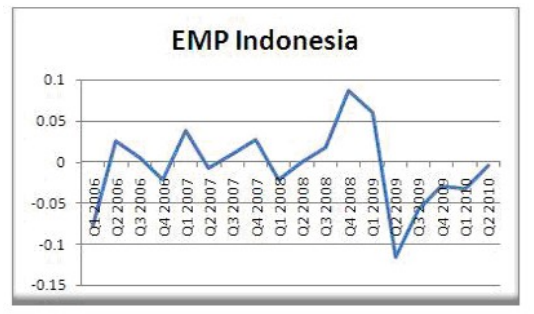

Graph 4

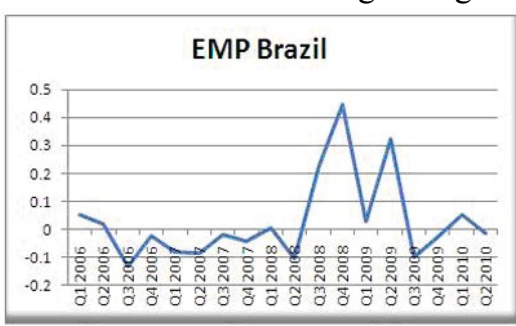

Graph 2

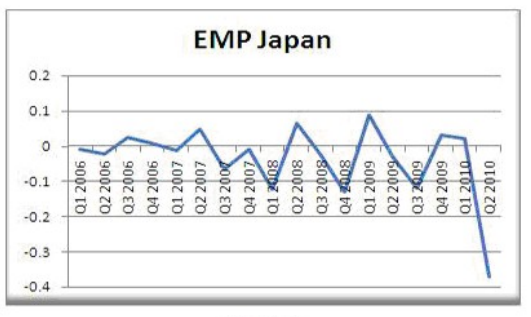

Graph 5

\subsubsection{Impulse functions}

Table 2 describes the impulse responses of the eight countries from VAR estimation. From the table, a change in the EMP of Argentina affected all the countries. Brazil and Canada were affected for three terms, whereas Mexico was affected the least by Argentina's EMP.

Crisis from Brazil impacted Korea, Mexico and Russia; with Russia being affected the most. Crisis originating from Canada impacted Japan and Korea the

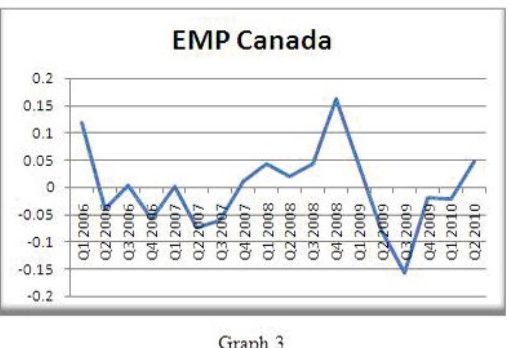

Graph 3

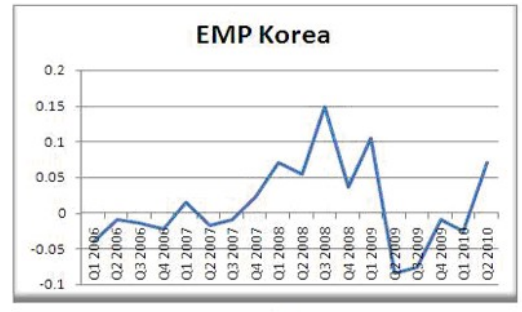

Graph 6

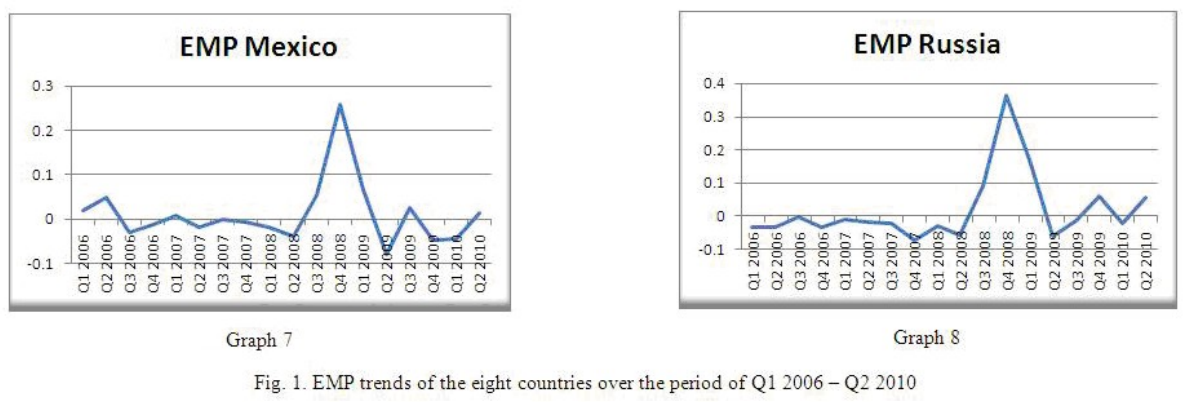

The combined EMP and Exports Growth trends of the eight countries over the period of Q1 2006 - Q2

2010 are shown in the figures 2 and 3 below ( $x$-axis represents the eighteen quarters of the above period).

\subsection{Nature of the Transmission of Crisis}

VAR model is used to find the correlations between the variables. The ordering of the variables used for Impulse responses and Variance decomposition is Argentina, Brazil, Canada, Indonesia, Japan, Korea, Mexico and Russia. most, whereas the effect was least for Russia.

The effect of crisis from Indonesia was transmitted to Brazil the most, where the impact lasted for all the four terms. Russia was impacted the least by crisis transmission from Indonesia. Crisis transmission from Japan had almost similar impacts on all the countries. Crisis from Korea affected Japan the most, where the impact lasted for three periods. 
Table 2. Reaction variables of the eight countries

\begin{tabular}{|c|c|c|c|c|c|c|c|c|c|c|c|}
\hline \multirow[b]{2}{*}{$\begin{array}{c}\text { Shock } \\
\text { Countries }\end{array}$} & \multicolumn{5}{|c|}{ Reaction of affected countries } & \multirow[b]{2}{*}{$\begin{array}{c}\text { Shock } \\
\text { Countries }\end{array}$} & \multicolumn{5}{|c|}{ Reaction of affected countries } \\
\hline & Country & $\begin{array}{c}1^{\text {st }} \\
\text { Term } \\
\end{array}$ & $\begin{array}{c}2^{\text {nd }} \\
\text { Term } \\
\end{array}$ & $\begin{array}{c}3^{\text {rd }} \\
\text { Term } \\
\end{array}$ & $\begin{array}{c}4^{\text {th }} \\
\text { Term } \\
\end{array}$ & & Country & $\begin{array}{c}1^{\text {st }} \\
\text { Term } \\
\end{array}$ & $\begin{array}{c}2^{\text {nd }} \\
\text { Term } \\
\end{array}$ & $\begin{array}{c}3^{\text {rd }} \\
\text { Term } \\
\end{array}$ & $\begin{array}{c}4^{\text {th }} \\
\text { Term }\end{array}$ \\
\hline \multirow{8}{*}{ Argentina } & Argentina & .1901 & - & .1936 & - & \multirow{8}{*}{ Japan } & Argentina & .0173 & - & .0398 & - \\
\hline & Brazil & .0495 & .0199 & .0548 & - & & Brazil & - & .0065 & - & - \\
\hline & Canada & - & .0627 & .0130 & .0890 & & Canada & - & .0128 & - & .0022 \\
\hline & Indonesia & - & .0990 & - & .0859 & & Indonesia & - & .0074 & - & .0112 \\
\hline & Japan & .0940 & - & - & - & & Japan & .0474 & - & .0240 & .0077 \\
\hline & Korea & .0422 & .0904 & - & .0740 & & Korea & .0066 & - & - & .0144 \\
\hline & Mexico & - & - & .0091 & - & & Mexico & - & .0055 & - & - \\
\hline & Russia & - & .1708 & - & .1477 & & Russia & - & .0199 & - & .0093 \\
\hline \multirow{8}{*}{ Brazil } & Argentina & .0295 & - & .0449 & - & \multirow{8}{*}{ Korea } & Argentina & - & .0185 & - & .0337 \\
\hline & Brazil & .0031 & .0278 & .0270 & .0289 & & Brazil & - & .0094 & .0113 & - \\
\hline & Canada & - & - & - & .0310 & & Canada & - & - & .0210 & - \\
\hline & Indonesia & - & .0319 & - & .0395 & & Indonesia & .0106 & - & .0162 & - \\
\hline & Japan & - & - & .0255 & - & & Japan & .0028 & .0151 & - & .0215 \\
\hline & Korea & - & .0107 & .0171 & .0347 & & Korea & .0176 & - & .0145 & .0029 \\
\hline & Mexico & .0147 & .0104 & .0098 & - & & Mexico & - & .0077 & - & - \\
\hline & Russia & .0252 & .0681 & - & .0652 & & Russia & .0157 & - & .0161 & - \\
\hline \multirow{8}{*}{ Canada } & Argentina & - & .0027 & - & .0099 & \multirow{8}{*}{ Mexico } & Argentina & - & .0011 & - & - \\
\hline & Brazil & - & .0134 & .0072 & - & & Brazil & .0021 & - & .0054 & .0125 \\
\hline & Canada & - & - & .0117 & .0025 & & Canada & - & - & - & .0075 \\
\hline & Indonesia & .0039 & - & .0072 & - & & Indonesia & - & .0023 & .0045 & .0039 \\
\hline & Japan & .0169 & .0051 & - & .0103 & & Japan & - & .0067 & .0101 & - \\
\hline & Korea & .0085 & - & .0136 & .0043 & & Korea & - & .0070 & .0051 & .0022 \\
\hline & Mexico & .0044 & .0064 & - & - & & Mexico & .0038 & - & .0060 & .0027 \\
\hline & Russia & .0030 & - & - & - & & Russia & .0076 & - & .0027 & .0054 \\
\hline \multirow{8}{*}{ Indonesia } & Argentina & - & .0070 & - & .0048 & \multirow{8}{*}{ Russia } & Argentina & - & .0032 & - & .0099 \\
\hline & Brazil & .0042 & .0046 & .0054 & .0058 & & Brazil & - & .0082 & .0133 & .0093 \\
\hline & Canada & - & - & - & .0048 & & Canada & - & - & .0026 & - \\
\hline & Indonesia & - & - & .0055 & - & & Indonesia & - & - & .0125 & .0026 \\
\hline & Japan & - & .0131 & .0102 & .0045 & & Japan & - & - & - & .0055 \\
\hline & Korea & - & - & .0093 & - & & Korea & - & - & .0112 & .0098 \\
\hline & Mexico & .0053 & .0020 & .0025 & - & & Mexico & - & .0043 & .0022 & .0029 \\
\hline & Russia & .0082 & - & - & - & & Russia & .0141 & .0052 & .0123 & .0038 \\
\hline
\end{tabular}

Note: The impulse coefficients lower than .002 are not reported.

Estimated results are based on the ordering of Argentina, Brazil, Canada, Indonesia, Japan, Korea, Mexico, and Russia.

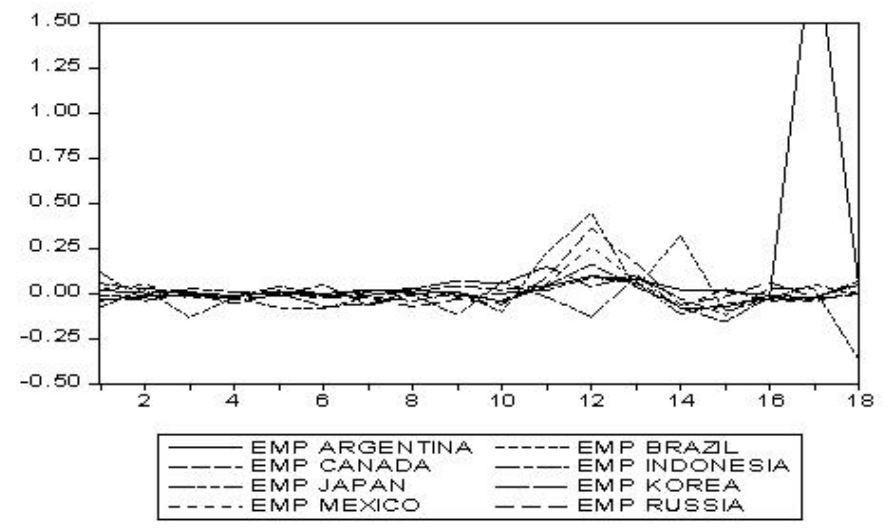

Fig. 2. Combined EMP trends of the eight countries over the period of Q1 2006-Q2 2010

Crisis originating from Mexico impacted Brazil, Indonesia, Korea and Russia for three terms; whereas the crisis from Russia was transmitted to Brazil and Mexico the most. 
Summarizing, Argentina, Brazil and Mexico had strong impacts on most of the countries. Brazil and Russia were mutually transmitting, which means that the crisis from Brazil impacted Russia strongly and vice versa.

\subsubsection{Variance decomposition analysis}

Variance decomposition explains the contribution of other countries in the EMP variance of a country.

Referring to Table 3, Indonesia explains its variance the most ( $47 \%$ of the EMP variance), whereas Mexico explaining the least ( $9 \%$ of the EMP variance). Self-
Japan impacted most of the eight countries $(18 \%$ share in Argentina's variance, 21\% in Brazil's, $15 \%$ in Korea's EMP variance, $27 \%$ in Mexico's and 16\% share in Russia's EMP variance), whereas Argentina (29\%) and Russia (15\%) had fair shares in Japan's EMP variance.

\subsection{Estimation Results for Transmission of Crisis}

From the above analysis of variance decomposition, two countries are selected having the strongest impacts on a country's EMP. These two impacting countries' EMPs were used as the explanatory variables for the country.

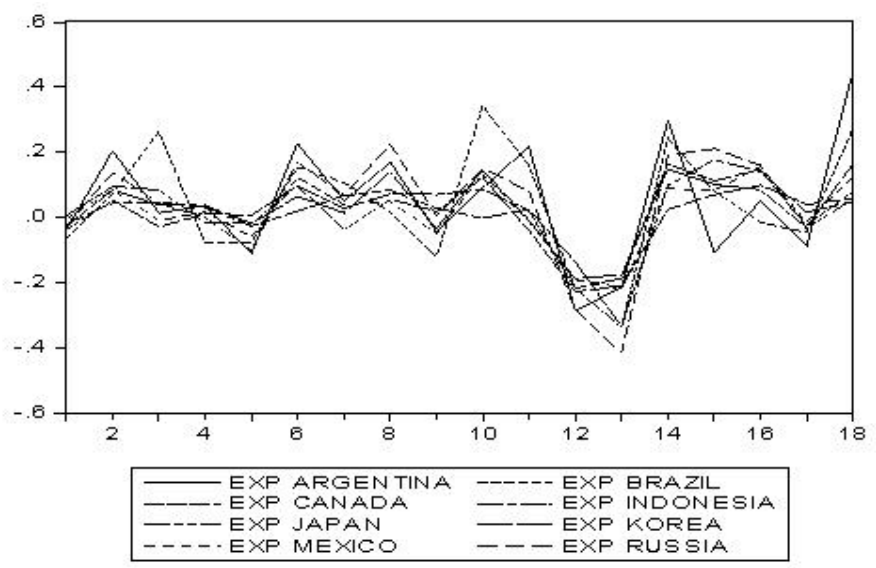

Fig. 3. Combined Export Growth trends of the eight countries over the period of Q1 2006-Q2 2010

Table 3. Variance decomposition of the eight countries

\begin{tabular}{ccccccccc}
\hline & Argentina & Brazil & Canada & Indonesia & Japan & Korea & Mexico & Russia \\
\hline Argentina & 35 & 3 & 4 & 6 & 18 & 9 & 2 & 23 \\
\hline Brazil & 18 & 22 & 6 & 5 & 21 & 6 & 1 & 20 \\
\hline Canada & 7 & 42 & 28 & 3 & 8 & 6 & 3 & 3 \\
\hline Indonesia & 5 & 10 & 12 & 47 & 8 & 9 & 2 & 7 \\
\hline Japan & 29 & 6 & 5 & 4 & 28 & 9 & 2 & 15 \\
\hline Korea & 24 & 7 & 6 & 7 & 15 & 26 & 2 & 13 \\
\hline Mexico & 11 & 23 & 13 & 1 & 27 & 13 & 9 & 4 \\
\hline Russia & 9 & 20 & 8 & 9 & 16 & 6 & 8 & 25 \\
\hline
\end{tabular}

The order of variables used for Variance Decomposition Analysis is Argentina, Brazil, Canada, Indonesia, Japan, Korea, Mexico, and Russia.

explaining EMP variances for Argentina, Brazil, Canada, Japan, Korea and Russia were recorded to be 35\%, 22\%, $28 \%, 28 \%, 26 \%$ and $25 \%$ respectively.

Low self-explanatory powers of the EMP variances show that all the countries were impacted by other countries in period under consideration.
Table 4 shows the estimation equation results. Results of Table 4 can be summarized as:

1. During pre-crisis period, Brazil's EMP was impacted by Japan and Russia. Indonesia's EMP was affected by Canada, whereas Mexico's EMP 
Table 4. Transmission Estimation Results

\begin{tabular}{|c|c|c|c|c|c|c|c|c|}
\hline & Argentina & Brazil & Canada & Indonesia & Japan & Korea & Mexico & Russia \\
\hline Inception & $\begin{array}{l}.028 \\
(.11)\end{array}$ & $\begin{array}{l}.024 \\
(.48)\end{array}$ & $\begin{array}{l}.013 \\
(.60)\end{array}$ & $\begin{array}{l}.018 \\
(.88)\end{array}$ & $\begin{array}{l}.006 \\
(.35)\end{array}$ & $\begin{array}{c}-.042 \\
(-2.14)^{* *}\end{array}$ & $\begin{array}{l}.002 \\
(.12)\end{array}$ & $\begin{array}{l}-. .009 \\
(-.50)\end{array}$ \\
\hline Inception - D & $\begin{array}{l}.083 \\
(.28) \\
\end{array}$ & $\begin{array}{l}.058 \\
(.88)\end{array}$ & $\begin{array}{l}-.006 \\
(-.19)\end{array}$ & $\begin{array}{l}-.008 \\
(-.26)\end{array}$ & $\begin{array}{c}.01 \\
(.34)\end{array}$ & $\begin{array}{l}-.050 \\
(1.67) \\
\end{array}$ & $\begin{array}{l}-. .006 \\
(-.21)\end{array}$ & $\begin{array}{l}.003 \\
(.11)\end{array}$ \\
\hline $\begin{array}{c}\text { Export Growth } \\
\text { Rate } \\
\end{array}$ & $\begin{array}{c}.921 \\
(1.02) \\
\end{array}$ & $\begin{array}{l}-.309 \\
(-1.43) \\
\end{array}$ & $\begin{array}{l}.188 \\
(.96) \\
\end{array}$ & $\begin{array}{l}-. .034 \\
(-.18) \\
\end{array}$ & $\begin{array}{l}-.146 \\
(-.97) \\
\end{array}$ & $\begin{array}{l}.164 \\
(.83) \\
\end{array}$ & $\begin{array}{l}.069 \\
(.53) \\
\end{array}$ & $\begin{array}{c}.204 \\
(1.67) \\
\end{array}$ \\
\hline $\begin{array}{c}\text { Export Growth } \\
\text { Rate - D }\end{array}$ & $\begin{array}{l}-1.932 \\
(-1.63)\end{array}$ & $\begin{array}{l}.191 \\
(.65) \\
\end{array}$ & $\begin{array}{c}-.29 \\
(-.88)\end{array}$ & $\begin{array}{l}-.231 \\
(-.86)\end{array}$ & $\begin{array}{l}.236 \\
(.79) \\
\end{array}$ & $\begin{array}{l}.222 \\
(.72)\end{array}$ & $\begin{array}{l}.026 \\
(.11)\end{array}$ & $\begin{array}{l}-.218 \\
(-1.09)\end{array}$ \\
\hline $\boldsymbol{\beta}_{i w}$ & $\begin{array}{c}.747 \\
(1.28)\end{array}$ & $\begin{array}{c}-.719 \\
(-2.91)^{* * *}\end{array}$ & $\begin{array}{c}-.15 \\
(-1.73)\end{array}$ & $\begin{array}{l}-.03 \\
(-.57)\end{array}$ & $\begin{array}{c}-.338 \\
(-4.62) * * *\end{array}$ & $\begin{array}{c}.137 \\
(1.60)\end{array}$ & $\begin{array}{l}-. .003 \\
(-.04)\end{array}$ & $\begin{array}{c}.136 \\
(1.66)\end{array}$ \\
\hline $\boldsymbol{\beta}_{i w}-\mathbf{D}$ & $\begin{array}{l}-.473 \\
(-.59)\end{array}$ & $\begin{array}{c}.742 \\
(2.66)^{* *}\end{array}$ & $\begin{array}{c}.124 \\
(1.26) \\
\end{array}$ & $\begin{array}{l}-.076 \\
(-.70)\end{array}$ & $\begin{array}{c}.298 \\
(2.59)^{* *}\end{array}$ & $\begin{array}{l}-. .096 \\
(-.70)\end{array}$ & $\begin{array}{l}.003 \\
(.04)\end{array}$ & $\begin{array}{l}-.061 \\
(-.31)\end{array}$ \\
\hline $\mathbf{E M P}_{\text {arg }}$ & & & & & $\begin{array}{l}.021 \\
(.58) \\
\end{array}$ & $\begin{array}{l}-.014 \\
(-.38) \\
\end{array}$ & & \\
\hline $\mathbf{E M P}_{\text {arg }}-\mathbf{D}$ & & & & & $\begin{array}{l}-.040 \\
(-.79) \\
\end{array}$ & $\begin{array}{l}.040 \\
(.78) \\
\end{array}$ & & \\
\hline $\mathbf{E M P}_{\text {bra }}$ & & & $\begin{array}{c}.209 \\
(1.83) \\
\end{array}$ & $\begin{array}{l}-.125 \\
(-.85) \\
\end{array}$ & & & $\begin{array}{c}.265 \\
(2.83)^{* * *} \\
\end{array}$ & $\begin{array}{c}.587 \\
(4.26)^{* * *}\end{array}$ \\
\hline $\mathbf{E M P}_{\text {bra }}-\mathbf{D}$ & & & $\begin{array}{l}-.03 \\
(-.19)\end{array}$ & $\begin{array}{l}.190 \\
(.99)\end{array}$ & & & $\begin{array}{c}-.210 \\
(-1.69)\end{array}$ & $\begin{array}{c}-.559 \\
(-3.24)^{* * *}\end{array}$ \\
\hline $\mathbf{E M P}_{\text {can }}$ & & & & $\begin{array}{c}.609 \\
(2.00)^{*} \\
\end{array}$ & & & & \\
\hline $\mathbf{E M P}_{\text {can }}-\mathbf{D}$ & & & & $\begin{array}{c}-1.504 \\
(- \\
3.76)^{* * *} \\
\end{array}$ & & & & \\
\hline \multicolumn{9}{|l|}{$\mathbf{E M P}_{\text {ind }}$} \\
\hline \multicolumn{9}{|l|}{$\mathbf{E M P}_{\text {ind }}-\mathbf{D}$} \\
\hline $\mathbf{E M P}_{\text {jap }}$ & $\begin{array}{l}2.884 \\
(1.45) \\
\end{array}$ & $\begin{array}{c}-1.206 \\
(-2.41)^{* *} \\
\end{array}$ & $\begin{array}{c}-37 \\
(-1.56) \\
\end{array}$ & & & $\begin{array}{c}315 \\
(1.19) \\
\end{array}$ & $\begin{array}{l}-. .118 \\
(-.81) \\
\end{array}$ & $\begin{array}{c}.407 \\
(1.28) \\
\end{array}$ \\
\hline $\mathbf{E M P}_{\text {jap }}-\mathbf{D}$ & $\begin{array}{l}-4.719 \\
(-1.57) \\
\end{array}$ & $\begin{array}{l}.551 \\
(.7) \\
\end{array}$ & $\begin{array}{c}.614 \\
(1.86) \\
\end{array}$ & & & $\begin{array}{c}.354 \\
(1.00) \\
\end{array}$ & $\begin{array}{l}-.310 \\
(-1.34) \\
\end{array}$ & $\begin{array}{l}.077 \\
(.19) \\
\end{array}$ \\
\hline \multicolumn{9}{|l|}{$\mathbf{E M P}_{\text {kor }}$} \\
\hline \multicolumn{9}{|l|}{$\mathbf{E M P}_{\text {kor }}-\mathbf{D}$} \\
\hline \multicolumn{9}{|l|}{$\mathbf{E M P}_{\text {mex }}$} \\
\hline \multicolumn{9}{|l|}{$\mathbf{E M P}_{\mathrm{mex}}-\mathrm{D}$} \\
\hline $\mathbf{E M P}_{\text {rus }}$ & $\begin{array}{l}-.493 \\
(-.43)\end{array}$ & $\begin{array}{c}.998 \\
(3.16) * * *\end{array}$ & & & $\begin{array}{c}-.216 \\
(-1.38)\end{array}$ & & & \\
\hline $\mathbf{E M P}_{\text {rus }}-\mathbf{D}$ & $\begin{array}{l}4.002 \\
(1.1)\end{array}$ & $\begin{array}{l}-.498 \\
(-.56)\end{array}$ & & & $\begin{array}{c}1.116 \\
(3.16)^{* * *}\end{array}$ & & & \\
\hline $\mathbf{R}^{2}$ & .18 & .41 & .29 & .41 & .56 & .40 & .41 & .50 \\
\hline
\end{tabular}

$* * *, * *,{ }^{*}$ denote significance at $1 \%, 5 \%$ and $10 \%$ level, respectively. White's robust $t$-tests are in parentheses.

was impacted by Brazil. Brazil also affected Russia

in this period.

2. During Global financial crisis,

(i) Argentina, Canada and Korea were not affected by the other countries. This shows that the EMPs for these countries did not change much, structurally.

(ii) Indonesia, Japan and Russia showed signs of wake-up call effect. Indonesia was impacted by crisis from Canada, whereas Japan was impacted by crisis from Russia. Russia was subject to crisis from Brazil. 
(iii) None of the eight countries showed significant results for export growth impact. This implies that competitive devaluation effect did not play major role in the transmission of crisis among the eight countries under consideration.

(iv) Brazil and Japan showed signs of cash-in effect. This shows that these two countries were impacted by crisis, significantly, due to the outflow of capital from these countries.

(v) None of the countries showed significant results for the intersect coefficients, which indicates that these countries were subject to crisis transmission due to above-mentioned four effects.

The results of estimation show that the competitive devaluation effect did not play major role in the transmission of crisis among the eight countries. This study shows that wake-up call effect and cash-in effect played significant roles in the crisis transmission among the considered countries.

\section{Conclusion}

This paper has focused on the channels through which Global financial crisis was transmitted among different countries. The crisis transmission was studied for eight countries which include Argentina, Brazil, Canada, Indonesia, Japan, Korea, Mexico and Russia. The channels considered for transmission were the competitive devaluation effect, the wake-up call effect and the cash-in effect. VAR and OLS estimations led to the following results:

1. Before the Global Financial broke out, Korea and Russia did not show any crisis signs. Russia and Korea were hit by crisis in the third quarter of 2008 . Korea started showing signs of a crisis episode from the last quarter of 2007. Argentina was hit severely by crisis in the first quarter of 2010. Brazil, Canada and Mexico were impacted by crisis in the later half of 2008. Indonesia and Japan did not hugely respond to the Global Financial Crisis.

2. Impulse responses for the eight countries showed that Argentina, Brazil and Mexico had strong impacts on most of the countries. Brazil and Russia were mutually transmitting, which means that the crisis from Brazil impacted Russia strongly and vice versa. Crisis transmission from Japan had impacts on all the countries. The effect of crisis from Indonesia was transmitted to Brazil, the most.

3. Estimation results evidence indicates that competitive devaluation effect did not play major part in the transmission of Global financial crisis. The significant channels of crisis transmission were wake-up call effect and the cash-in effect. Indonesia, Japan and Russia showed signs of wakeup call effect. Indonesia was impacted by crisis from Canada, whereas Japan was impacted by crisis from Russia. Russia was subject to crisis from Brazil. Brazil and Japan showed signs of cash-in effect, indicating the outflow of capital from these countries.

\section{References}

1. M. H. Naveh, T. Torosyan and S.A. Jalaee, Regional economic integration and its effects on economic growth and economic welfare. World Applied Sciences Journal, 17(10) (2012), 1349-1355.

2. S-C. Gong, T-P. Lee and Y-M. Chen, Crisis transmission: Some evidence from the Asian financial crisis. International Review of Financial Ana lysis, 13 (2004), 463-478.

3. J.A. Frankel and A.K. Rose, (1996). Currency crashes in emerging markets: An empirical treatment. Journal of International Economics, 41 (1996), 351-366.

4. M. Fratzscher, On currency crises and contagion. Working Paper Series 139 (2002), European Central Bank.

5. H. Bremnes, O. Gjerde and F. Soettem, Linkages among interest rates in the United States, Germany and Norway. The Scandinavian Journal of Economics , 103(1) (2001), 127-145.

6. V. Pukeliene and I. Deksnyte, Currency crises: Models and their possibility in Lithuania. Economics and Management, 15 (2010), 206-211.

7. W.R. White, Crisis contagion in Asia: Causes and preventive measures. Swiss Journal of Econo mic and Statistics, 134 (1998), 722. In Markus Staub, 'Discussion on International Contagion: What is it and what can be done against it?'

8. M. Goldstein, The Asian financial crisis causes, cures and systematic implications. Institute for International Economics, Washington D.C., 1998.

9. Abdullah, M. Asghar and Z. Abbas, Financial crisis in Asia - The transmission: A regression based approach. 
Interdisciplinary Journal of Contemporary Research in Business, 2(11) (2011), 210-227.

10. G. Kaminsky, S. Lizondo and C.M. Reinhart, Leading indicators of currency crises. IMF Staff Papers, 45 (1998), $1-48$.

11. T. Komulainen and J. Lukkarila, What drives financial crises in emerging markets? Emerging Markets Review, 4 (2003), 248-272. 